\title{
PENGEMBANGAN MODUL FISIKA BERBASIS GUIDED INQUIRY UNTUK MENINGKATKAN KEMAMPUAN BERPIKIR KRITIS PESERTA DIDIK
}

\author{
Widya Triandini' ${ }^{1}$, Kosim¹), I Wayan Gunada') \\ 1)Program Studi Pendidikan Fisika, FKIP, Universitas Mataram, NTB \\ Corresponding author : Widya Triandini \\ E-mail : widyaixb40@gmail.com
}

Diterima 26 Januari 2021, Direvisi 01 Februari 2021, Disetujui 01 Februari 2021

\begin{abstract}
ABSTRAK
Penelitian ini bertujuan untuk menghasilkan produk berupa modul fisika berbasis guided inquiry yang layak, efektif, dan praktis. Kelayakan modul ditinjau dari validasi modul yang selanjutnya digunakan untuk meningkatkan kemampuan berpikir kritis peserta didik. Desain penelitian yang digunakan adalah model 4D yang terdiri dari define, design, develop dan disseminate. Teknik pengumpulan data menggunakan lembar validasi, instrumen tes kemampuan berpikir kritis dan angket respon peserta didik terhadap modul. Data validitas dianalisis dengan menentukan CVI oleh validator ahli. Hasil analisis CVI modul fisika berbasis guided inquiry oleh dosen ahli sebesar 0,99 yang termasuk kategori sangat baik, sedangkan hasil analisis $\mathrm{CVI}$ oleh praktisi sebesar 0,89 yang termasuk kategori sangat baik. Data pretest dan posttest dianalisis untuk menentukan peningkatan kemampuan berpikir kritis peserta didik melalui uji $n$-gain. Hasil analisis data diperoleh rata-rata $n$-gain sebesar 0,44 dengan kategori sedang yang menunjukkan terjadi peningkatan kemampuan berpikir kritis. Berdasarkan hasil analisis angket respon peserta didik terhadap modul menunjukkan kriteria positif dengan perolehan rerata sebesar $76,9 \%$. Hasil tersebut dapat disimpulkan bahwa produk yang dikembangkan sangat layak, efektif, dan praktis digunakan dalam pembelajaran.
\end{abstract}

Kata kunci: modul, guided inquiry, berpikir kritis.

\begin{abstract}
This study aims to produce a product in the form of a physics module based on guided inquiry that is feasible, effective, and practica used. The feasibility of the module is viewed from the module validation which is then used to improve students' critical thinking skills. The research design used is the 4D model which consists of define, design, develop, and disseminate. Data collection techniques used validation sheets, critical thinking skills test instruments, and student response questionnaires to the module. Validity data were analyzed by determining CVI by expert validators. The results of the CVI analysis on the product by expert lecturers were 0.99 which was in the very good category, while the results of the $\mathrm{CVI}$ analysis by practitioners were 0.89 which was in the very good category. The pretest and posttest data were analyzed to determine the increase in students' critical thinking skills through the n-gain test. The results of data analysis obtained an average n-gain of 0.44 in the medium category which indicates an increase in critical thinking abilities. Based on the results of the questionnaire analysis, the responses of students to the module showed positive criteria with an average acquisition of $76.9 \%$. These results can be concluded that the product developed is very feasible, effective, and practical to use in learning.
\end{abstract}

Keywords: module, guided inquiry, critical thinking.

\section{PENDAHULUAN}

Pendidikan menjadi salah satu tolak ukur untuk menentukan kualitas suatu negara dalam menumbuhkan kecakapan generasi penerus bangsa guna bersaing secara global dalam menghadapi dan memecahkan permasalahan dunia. Pendidikan yang berkualitas dan bermutu dapat melahirkan sumber daya manusia yang unggul baik dari segi kognitif, afektif, dan psikomotorik. Seiring berjalannya waktu, guna tercapainya tujuan pendidikan nasional, pemerintah terus melakukan upaya pengembangan dan perbaikan terhadap sistem pendidikan dengan mengembangkan kurikulum. Kurikulum adalah salah satu unsur yang memberikan kontribusi untuk mewujudkan perkembangan kualitas potensi peserta didik (Sahidu, 2018). Kurikulum merupakan seperangkat rencana yang dijadikan acuan penyelenggaraan kegiatan belajar mengajar yang berisi muatan pembelajaran dan cara pelaksaannya. 
Implementasi kurikulum 2013 dalam pembelajaran di Indonesia diharapkan dapat meningkatkan potensi lulusan dengan mengasah keterampilan berpikir tingkat tinggi khususnya berpikir kritis peserta didik sehingga dapat bersaing di era globalisasi. Cahyono (2017) berpendapat bahwa daya saing individu dalam berkompetisi dapat ditentukan dengan kemampuan berpikir kritisnya. Kemampuan berpikir kritis merupakan cara berpikir untuk menentukan keputusan atau tindakan yang tepat dengan mempertanyakan hal-hal yang berhubungan dengan informasi secara logis. Pembelajaran fisika merupakan salah satu mata pelajaran yang dapat membantu peserta didik dalam mengasah kemampuan berpikir kritis (Hartawati et al, 2020). Pembelajaran fisika seyogyanya dapat memberikan pengalaman langsung agar peserta didik terlibat aktif dalam pembelajaran dengan menerapkan model pembelajaran yang mendukung.

Dibutuhkan suatu model pembelajaran yang dapat diterapkan pada kegiatan belajar mengajar untuk melatih kemampuan berpikir kritis peserta didik. Salah satu model yang dapat diterapkan adalah model guided inquiry. Model guided inquiry mendorong peserta didik untuk secara aktif menggali informasi mengenai suatu masalah yang diajukan guru melalui petunjuk yang diberikan untuk menemukan solusi melalui penyelidikan atau percobaan. Sabaryati \& Darmayanti (2018) menyatakan bahwa pembelajaran fisika dengan model guided inquiry bukan hanya memperoleh teori, namun juga berkaitan dengan karakter ilmiah yang dapat ditumbuhkan melalui kegiatan pengamatan dengan melakukan eksperimen. Inti dari pembelajaran inquiry adalah pengetahuan yang diperoleh peserta didik tidak hanya sekedar fakta dan teori, tetapi mengacu pada kegiatan pembelajaran yang bersifat menemukan pengetahuannya sendiri dengan arahan dari guru (Trisna \& Rahmi, 2016). Guided inquiry adalah model pembelajaran yang dapat membantu peserta didik untuk memecahkan masalah dengan berbagai alternatif solusi melalui proses berpikir dan penyelidikan serta guru hanya bertindak sebagai fasilitator dan pembimbing. Pelaksanaan pembelajaran dengan guided inquiry menurut Sugiyanto, et al. (2013) akan optimal jika didukung dengan media berupa modul.

Media digunakan untuk memudahkan guru menyampaikan materi dalam proses belajar mengajar sehingga dapat merangsang pikiran, perhatian, dan minat belajar peserta didik. Media berbasis visual memegang peranan penting dalam proses pembelajaran
(Muldiyana, et al., 2018). Modul merupakan salah satu media pembelajaran yang dikemas secara sistematis agar peserta didik dapat melakukan pembelajaran secara mandiri tanpa didampingi guru. Penggunaan modul dapat mengakomodasi peserta didik yang memilliki tingkat kecepatan belajar yang tinggi, sehingga dapat belajar lebih cepat dan menyelesaikan latihan soal lebih cepat pula, begitupun sebaliknya peserta didik yang tingkat kecepatan belajarnya lebih lambat dapat mengulang kembali pelajaran hingga memahami materi yang disajikan, maka peserta didik tidak akan tertinggal pelajaran.

Pembelajaran fisika dengan menggunakan modul dapat membantu guru dalam menyampaikan materi, dimana peserta didik dapat belajar mandiri, mengembangkan kemampuan berpikir sesuai kemampuan masing-masing, mengurangi ketergantungan terhadap guru, dan memudahkan dalam mempelajari setiap kompetensi. Peserta didik dapat mencapai dan menyelesaikan bahan belajarnya dengan modul dan dapat mengontrol kemampuan serta intensitas belajarnya (Auliya \& Kosim, 2017). Menurut Suryosubroto (dalam Permana, 2017), tujuan penggunaan modul selama pembelajaran berlangsung, antara lain yaitu tujuan pendidikan dapat dicapai secara efektif dan efisien, peserta didik dapat mengikuti pembelajaran sesuai kecepatan dan kemampuan sendiri, peserta didik dapat lebih banyak waktu untuk menghayati dan melakukan kegiatan belajar secara mandiri tanpa bimbingan guru, peserta didik dapat mengukur dan mengetahui hasil belajar secara mandiri, peserta didik menjadi pusat kegiatan belajar mengajar, kemajuan peserta didik diikuti dengan evaluasi di setiap kegiatan akhir, modul disusun berdasarkan konsep "mastery learning" yaitu konsep yang menekankan agar peserta didik secara optimal menguasai materi yang disajikan dalam modul. Pembelajaran mandiri kini menjadi kebutuhan hampir setiap peserta didik di seluruh penjuru dunia terutama Indonesia akibat pandemi Covid-19 yang menghambat keterlaksanaan kegiatan belajar mengajar di sekolah. Sehingga dibutuhkan pengembangan modul sebagai media pendukung keterlaksanaan pembelajaran jarak jauh.

Berdasarkan uraian di atas, maka perlu dilakukan yang bertujuan untuk (1) menghasilkan modul fisika berbasis guided inquiry yang layak digunakan dalam pembelajaran untuk meningkatkan kemampuan berpikir kritis peserta didik; (2) mengetahui efektivitas modul fisika berbasis guided inquiry terhadap kemampuan berpikir kritis peserta didik; (3) mengetahui kepraktisan modul fisika 
berbasis guided inquiry untuk digunakan dalam pembelajaran.

\section{METODE PENELITIAN}

Jenis penelitian yang digunakan yaitu penelitian pengembangan (Research and Development). Penelitian ini merupakan penelitian pengembangan karena bertujuan untuk menghasilkan atau mengembangkan suatu modul. Penelitian pengembangan ini menggunakan desain penelitian yang mengacu pada desain 4D yang dikemukakan oleh Thiagarajan (dalam Al-Tabany, 2014) dan merupakan singkatan dari define, design, development, dan disseminate. Pemilihan model 4D ini karena tahapannya sesuai dengan tahapan pengembangan modul seperti yang dikemukakan Purwanto, et al. (2007) yang menyatakan agar sebaiknya penulisan modul mengikuti langkah-langkah berikut; 1) perencanaan, 2) penulisan, 3) review, uji coba, dan revisi, 4) finalisasi dan pencetakan. Namun, mengingat kondisi pandemi saat ini, uji coba yang dapat dilakukan peneliti hanya uji coba terbatas. Kemudian untuk tahap disseminate peneliti menyebarluaskan hasil penelitian dalam bentuk artikel ilmiah.

Validitas produk diuji menggunakan analisis Content Validity Ratio (CVR) dan Content Validity Index (CVI). CVR merupakan salah satu metode yang digunakan untuk mengukur validitas isi (Hendryadi, 2017). Cara menghitung nilai CVR menurut Lawshe dikutip dari Hendryadi (2017) yaitu dengan menggunakan persamaan berikut.

$$
C V R=\frac{\left(N_{e}-\frac{N}{2}\right)}{\frac{N}{2}}
$$

Dengan

$N_{e}=$ jumlah validator yang setuju

$N=$ jumlah total validator

Lawse dalam Azwar (2012) mengemukakan bahwa setelah semua skor dihitung dengan persamaan CVR, maka langkah berikutnya adalah menghitung indeks validitas produk dengan persamaan berikut.

$$
C V I=\frac{\text { jumlah seluruh } C V R}{\text { jumlah butir angket }}
$$

Rentang hasil nilai CVR dan CVI dapat dikategorikan seperti pada Tabel 1 berikut.

Tabel 1. Kategori nilai CVR dan CVI

\begin{tabular}{cl}
\hline Rentang Nilai & Kategori \\
\hline$-1<x<0$ & Tidak baik \\
$x=0$ & Baik \\
$0<x<1$ & Sangat baik \\
\hline & (Azwar, 2012)
\end{tabular}

Modul yang telah divalidasi kemudian kemudian direvisi sesuai saran dan masukan yang diberikan oleh validator. Setelah revisi barulah produk diuji coba untuk mengetahui keefektivan dan keprakitsan penggunaan produk untuk meningkatkan kemampuan berpikir kritis. Misbah et al, (2016) menjelaskan bahwa efektivitas modul diperoleh dari data hasil tes belajar peserta didik. Uji coba terbatas melibatkan beberapa peserta didik yang akan menggunakan modul fisika berbasis guided inquiry dalam pembelajaran. Indikator yang diukur adalah nilai hasil belajar peserta didik yang telah dirumuskan sesuai indikator berpikir kritis setelah menggunakan modul. Nilai pretest dan posttest ini akan digunakan untuk mencari bagaimana peningkatan kemampuan berpikir kritis peserta didik setelah menyelesaikan pembelajaran dengan modul. Peningkatan kemampuan berpikir kritis ini dapat dilihat dari perbandingan skor $\mathrm{N}$-gain yang dihitung dengan persamaan berikut.

$$
\langle g\rangle=\frac{\text { skor posttest }- \text { skor pretest }}{\text { skor maksimum }- \text { skor pretest }}
$$

Nilai $\mathrm{N}$-gain yang diperoleh dapat dikategorikan menggunakan interpretasi indeks gain ternormalisasi seperti pada tabel di bawah ini.

Tabel 2. Kriteria perolehan $N$-gain

\begin{tabular}{rc}
\hline Skor $\boldsymbol{N}$-Gain & Interpratesi \\
\hline $0,70<\langle g\rangle<1,00$ & Tinggi \\
$0,30<\langle g\rangle<0,70$ & Sedang \\
$0,00<\langle g\rangle<0,30$ & Rendah \\
\hline & (Sundayana, 2014)
\end{tabular}

Selain itu juga diperoleh angket respon peserta didik terhadap penggunaan modul untuk mengukur kepraktisannya. Menurut Wati, et al. (2017) untuk menilai kepraktisan suatu modul, dapat diukur berdasarkan penilaian dari angket respon peserta didik yang disebar setelah pembelajaran dengan modul selesai. Angket respon ini dibagi menjadi lima aspek penilaian, yaitu 1) bahasa dan tampilan, 2) kelayakan penyajian, 3) kualitas penyajian, 4) instruksional, dan 5) teknis. Analisis respon peserta didik dilakukan menghitung nilai total respon untuk setiap pertanyaan. Menurut Sudjana (dalam Ristanti, et al., 2019) persentase nilai respon peserta didik dapat dicari dengan persamaan:

$$
\% N R S=\frac{\sum N R S}{N R S \text { maksimal }} \times 100 \%
$$

Dengan NRS adalah nilai respon siswa yang diperoleh dari angket yang disebar kepada peserta didik dan diberi penilaian. Berdasarkan persentase yang diperoleh dari persamaan di 
atas, maka nilai respon peserta didik terhadap modul dapat dikategorikan seperti pada tabel di bawah ini.

Tabel 3. Kriteria Persentase Respon Peserta Didik

\begin{tabular}{cl}
\hline \multicolumn{1}{c}{ Interval } & \multicolumn{1}{c}{ Kriteria } \\
\hline $81,25 \%<N R S \leq 100 \%$ & Sangat positif \\
$62,5 \%<N R S \leq 81,25 \%$ & Positif \\
$43,75 \%<N R S \leq 62,5 \%$ & Kurang positif \\
$25 \%<N R S \leq 43,75 \%$ & Tidak positif \\
\hline \multicolumn{2}{c}{ (Sudjana dalam Ristanti et al, 2019) }
\end{tabular}

Modul dapat dikatakan praktis digunakan dalam pembelajaran apabila respon peserta didik terhadap modul dikategorikan sangat positif atau positif.

\section{HASIL DAN PEMBAHASAN Tahap Define}

Tahap define diartikan sebagai tahap untuk mendefinisikan syarat yang dibutuhkan untuk melakukan pengembangan terhadap modul. Tahap define dilakukan analisis awal, analisis peserta didik, analisis tugas, dan analisis konsep. Pada tahap ini peneliti melakukan studi literatur, observasi dan wawancara dengan guru fisika di sekolah. Pada analisis tugas dirumuskan isi dalam suatu pembelajaran dengan merinci isi materi ajar secara garis besar berdasarkan Kompetensi Inti dan Kompetensi Dasar yang sesuai dengan Kurikulum 2013. Pokok bahasan yang dikembangkan dalam penelitian ini adalah materi Fluida Statik dan Fluida Dinamik. Sedangkan pada analisis konsep diidentifikasi konsep-konsep pokok yang diajarkan dalam pembelajaran dan disusun hingga membentuk suatu peta konsep. Konsep-konsep pokok disusun secara rinci dan sistematis agar terkait dengan konsep yang relevan dalam kehidupan sehari-hari serta mengaitkan suatu konsep dengan konsep lainnya seperti yang ditunjukkan gambar berikut.

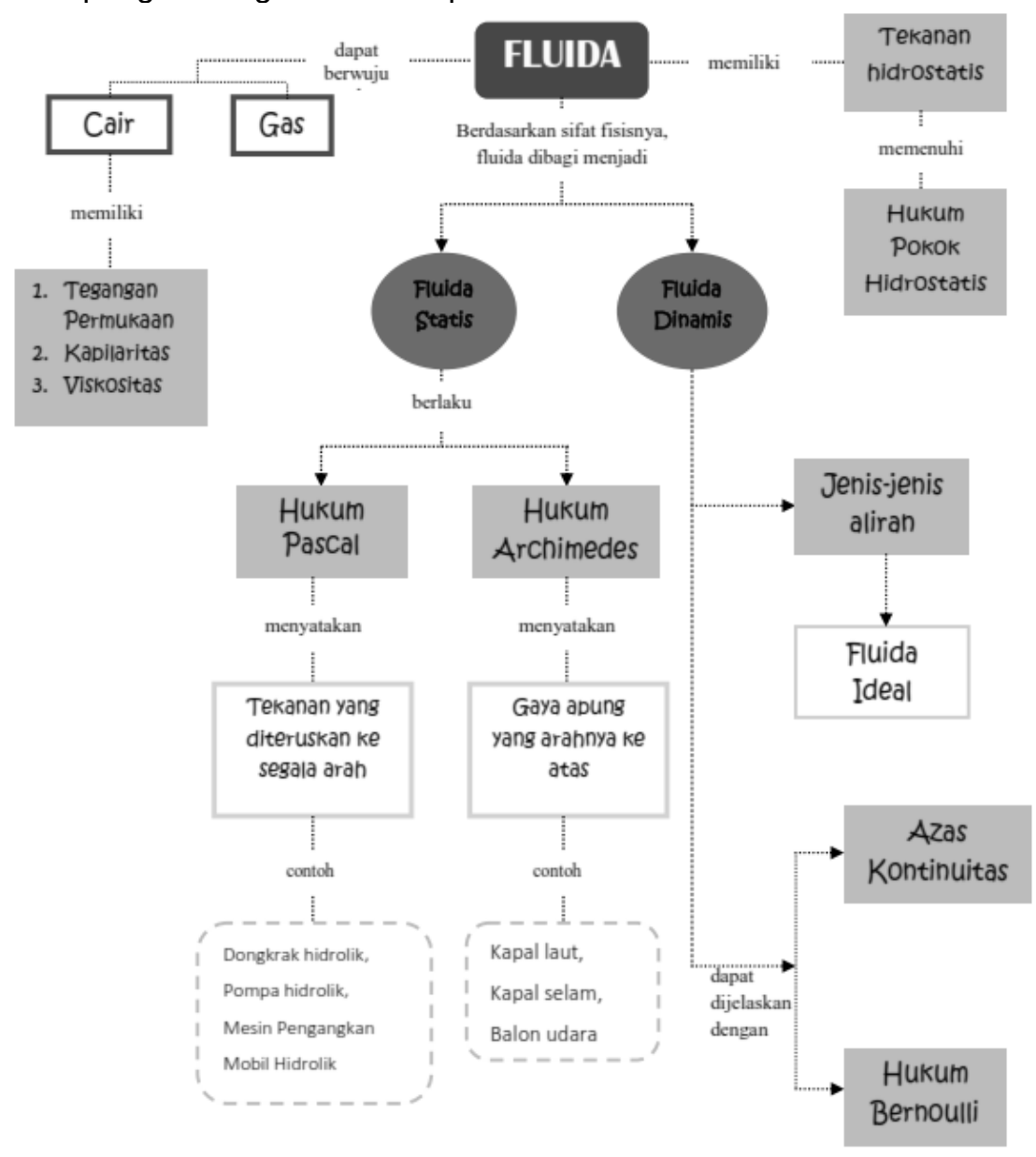

Gambar 1. Peta Konsep Materi Fluida

\section{Tahap Design}

Tahap design adalah tahap penyusunan draft awal yang dijadikan acuan kelayakan dan kualitas modul fisika berbasis guided inquiry yang meliputi aspek isi, kebahasaan, penyajian, dan kegrafisan. Pada tahap ini dilakukan pemilihan media pembelajaran, pemilihan format media, dan rancangan awal modul fisika berbasis guided inquiry yang digunakan dalam pembelajaran 
materi Fluida. Pada tahap ini dihasilkan draft untuk produk yang dikembangkan dilengkapi dengan perangkat pembelajaran (silabus dan RPP) dan instrumen tes kemampuan berpikir kritis yang mendukung pelaksanaan pembelajaran. Modul fisika berbasis guided inquiry pada materi Fluida ini dirancang berdasarkan pada sintaks guided inquiry yang melibatkan peserta didik secara aktif untuk terlibat dalam pembelajaran hingga mampu melatih kemampuan berpikir kritis. Sintaks model pembelajaran guided inquiry terdiri dari enam tahapan yaitu perumusan masalah, membuat hipotesis, merancang percobaan, melakukan percobaan, mengumpulkan dan menganalisis data, serta membuat kesimpulan (Tangkas, 2012).

Penyusunan modul fisika berbasis guided inquiry yang dikembangkan ini memperhatikan beberapa aspek, meliputi penyesuaian modul dengan materi pembelajaran, karakteristik modul yang baik, dan relevansi dengan model pembelajaran guided inquiry untuk meningkatkan kemampuan berpikir kritis peserta didik. Modul fisika berbasis guided inquiry dibagi menjadi 4 kegiatan belajar pada materi fluida statik dan 3 kegiatan belajar pada materi fluida dinamik. Pada setiap kegiatan belajar disajikan permasalahan dalam kehidupan sehari-hari berupa gambar dan deskripsi gambar untuk dilakukan identifikasi terhadap masalah tersebut dan kegiatan percobaan dilakukan dengan arahan/petunjuk yang tersedia di modul.

\section{Tahap Development}

Tahap pengembangan merupakan tahap dilakukan validasi terhadap modul fisika berbasis guided inquiry beserta perangkat pembelajaran dan instrumen tes oleh validator ahli yang terdiri dari tiga dosen dan tiga guru sebagai praktisi. Selanjutnya dilakukan uji coba terbatas pada 10 peserta didik kelas XI MIPA 5 di SMAN 7 Mataram. Hasil dari tahap pengembangan ini adalah data kualitatif dan kuantitatif. Data kualitatif diperoleh dari hasil validasi oleh validator ahli yang berupa saran dan masukan. Sedangkan data kuantitatif diperoleh dari hasil peniliaian validator terhadap produk pada lembar validasi menggunakan skala likert, angket respon peserta didik terhadap modul, serta nilai pretest dan posttest peserta didik.

Berdasarkan penilaian validator untuk modul ini secara keseluruhan sangat layak digunakan dengan perbaikan sesuai saran. Berdasarkan hasil analisis skor validasi keseluruhan kompenen modul oleh ketiga dosen diperoleh CVI sebesar 0,99 sehingga modul dikategorikan sangat baik. Adapun hasil analisis validasi oleh dosen untuk setiap komponen modul dapat dilihat pada Tabel 4 berikut ini.

Tabel 4. Hasil Validasi Modul oleh Dosen

\begin{tabular}{clcl}
\hline No. & $\begin{array}{c}\text { Komponen } \\
\text { Modul }\end{array}$ & CVI & Kategori \\
\hline 1. & Isi & 0,93 & Sangat baik \\
2. & Kebahasaan & 1 & Sangat baik \\
3. & Penyajian & 1 & Sangat baik \\
4. & Kegrafisan & 1 & Sangat baik \\
\hline
\end{tabular}

Hasil analisis skor validasi oleh ketiga praktisi untuk keseluruhan komponen modul diperoleh CVI sebesar 0,89 yang juga dikategorikan sangat baik. Hasil analisis validasi oleh guru (praktisi) untuk setiap komponen modul dapat dilihat pada Tabel 5 berikut ini.

Tabel 5. Hasil Validasi Modul oleh Guru

\begin{tabular}{clcl}
\hline No. & $\begin{array}{c}\text { Komponen } \\
\text { Modul }\end{array}$ & CVI & Kategori \\
\hline 1. & Isi & 0,79 & Sangat baik \\
2. & Kebahasaan & 1 & Sangat baik \\
3. & Penyajian & 0,86 & Sangat baik \\
4. & Kegrafisan & 1 & Sangat baik \\
\hline
\end{tabular}

Hal tersebut berarti bahwa modul fisika berbasis guided inquiry sangat valid atau sangat layak diterapkan dalam kegiatan pembelajaran. Hal tersebut sesuai dengan hasil penelitian yang dilakukan oleh Mariana, et al. (2017) dan Ariani, et al. (2018) yang melaporkan bahwa modul fisika berbasis inkuiri terbimbing layak digunakan untuk meningkatkan kemampuan berpikir kritis peserta didik dilihat dari hasil validasi. Secara umum, modul fisika berbasis guided inquiry ini mendapat perbaikan pada bagian cover, ilustrasi yang sesuai dengan penerapan konsep dalam kehidupan sehari-hari, cara penyampaian yang lebih komunikatif dengan peserta didik, dan penambahan bagian rangkuman materi. Saran yang diberikan oleh validator menjadi bahan masukan bagi peneliti untuk melakukan perbaikan, sehingga perangkat pembelajaran dapat digunakan pada uji coba terbatas (Fatmawati, 2016).

Peningkatan hasil belajar fisika peserta didik diukur melalui nilai pretest sebelum pembelajaran dan nilai posttest setelah diterapkannya pembelajaran menggunakan modul fisika berbasis guided inquiry. Hasil analisis yang telah dilakukan pada nilai pretest dan posttest masing-masing peserta didik digunakan untuk menghitung nilai standar gain secara keseluruhan, di mana dalam penelitian ini diperoleh nilai rata-rata $n$-gain sebesar 0,44 . Adapun secara ringkas, dari 10 peserta didik terdapat 1 peserta didik pada kategori tinggi, 8 peserta didik pada kategori sedang, dan 
sebanyak 1 peserta didik pada kategori rendah. Berdasarkan rata-rata pretest sebesar 31,40 dan posttest sebesar 62,00 untuk keseluruhan peserta didik seperti yang disajikan pada Tabel 6. Hal ini menunjukkan bahwa terjadi peningkatan kemampuan berpikir kritis fisika peserta didik pada materi Fluida Statik yang diajarkan menggunakan modul fisika berbasis guided inquiry.

Tabel 6. Analisis Rata-rata KBK melalui Uji Ngain pada Kelas XI MIPA 5

\begin{tabular}{ll}
\hline \multicolumn{1}{c}{ Rumus } & Nilai \\
\hline $\bar{X}$ Pretest & 31,40 \\
$\bar{X}$ Posttest & 62,00 \\
$\bar{X}$ Posttest $-\bar{X}$ Pretest & 30,6 \\
$100-\bar{X}$ Pretest & 68,6 \\
\hline Skor N-gain & 0,44 \\
\hline
\end{tabular}

Hal ini sejalan dengan penelitian yang dilakukan oleh Pratama, et al. (2019) terkait dengan pembelajaran dengan modul virtual berbasis inkuiri terbimbing yang menunjukkan adanya peningkatan dari kemampuan berpikir kritis peserta didik. Penelitian yang serupa sebelumnya pernah dilakukan oleh Mariana, et al. (2017) dalam pengembangan modul fisika berbasis inkuiri terbimbing untuk meningkatkan kemampuan berpikir kritis pada materi listrik dinamis. Hasil penelitian menunjukkan bahwa penerapan modul yang dikembangkan efektif dalam meningkatkan kemampuan berpikir kritis peserta didik. Hal ini diperoleh dari hasil nilai gain score yang tergolong dalam kategori sedang. Hal ini disebabkan karena modul disusun dengan sintaks dari model pembelajara guided inquiry yang mendorong peserta didik untuk lebih aktif dalam mengolah data hasil penyelidikan, kemudian mendiskusikannya untuk menemukan pemecahan masalah dan membuat kesimpulan. Kegiatan-kegiatan tersebut mampu memunculkan kemampuan berpikir kritis peserta didik. Selain itu, peserta didik juga merasakan langsung pengalaman belajarnya melalui percobaan sederhana yang disajikan dalam modul lengkap dengan petunjuknya.

Penilaian kepraktisan modul fisika berbasis guided inquiry diukur berdasarkan hasil nilai respon peserta didik terhadap penggunaan modul dalam pembelajaran pada tahap uji coba terbatas. Berdasarkan respon yang diperoleh dari 10 peserta didik yang mengikuti pelaksanaan pembelajaran menggunakan modul fisika berbasis guided inquiry diketahui bahwa nilai respon peserta didik terhadap penggunaan modul sebesar $76,9 \%$. Hasil analisis angket respon peserta didik disajikan secara ringkas seperti pada Tabel 7 di bawah ini.
Tabel 7. Hasil Angket Respon Peserta Didik terhadap Modul Fisika Berbasis Guided Inquiry

\begin{tabular}{|c|c|c|c|}
\hline $\begin{array}{c}\text { No } \\
\text {. }\end{array}$ & $\begin{array}{c}\text { Aspek } \\
\text { yang } \\
\text { Dinilai }\end{array}$ & $\begin{array}{c}\text { Persentas } \\
\text { e }(\%)\end{array}$ & $\begin{array}{c}\text { Kategor } \\
\text { i }\end{array}$ \\
\hline 1. & $\begin{array}{l}\text { Bahasa dan } \\
\text { tampilan } \\
\text { ( } 3 \text { indikator } \\
\text { penilaian) }\end{array}$ & 81,67 & $\begin{array}{l}\text { Sangat } \\
\text { positif }\end{array}$ \\
\hline 2. & $\begin{array}{l}\text { Kelayakan } \\
\text { penyajian } \\
\text { (4 indikator } \\
\text { penilaian) }\end{array}$ & 73,12 & Positif \\
\hline 3. & $\begin{array}{l}\text { Kualitas } \\
\text { penyajian } \\
\text { (3 indikator } \\
\text { penilaian) }\end{array}$ & 78,30 & Positif \\
\hline 4. & $\begin{array}{l}\text { Instruksiona } \\
\text { (4 indikator } \\
\text { penilaian) }\end{array}$ & 75,00 & Positif \\
\hline 5. & $\begin{array}{l}\text { Teknis } \\
\text { (4 indikator } \\
\text { penilaian) }\end{array}$ & 76,25 & Positif \\
\hline & Rata-rata & 76,9 & Positif \\
\hline
\end{tabular}

Hasil ini menunjukkan bahwa peserta didik memberikan respon positif berdasarkan kriteria yang ditetapkan oleh Sudjana (dalam Ristanti, et al., 2019). Hal ini sejalan dengan penelitian Haspen \& Festiyed (2019) yang memperoleh hasil bahwa penggunaan e-modul dengan model inkuiri terbimbing praktis diterapkan dalam pembelajaran fisika. Hal serupa juga terlihatdalam penelitian Matsun \& Saputri (2020) yang memperoleh hasil bahwa e-modul fisika layak, efektif, dan praktis digunakan sebagao alternatif pembelajaran di masa pandemi covid-19

\section{Tahap Disseminate}

Tahap akhir yaitu tahap disseminate atau tahap penyebaran. Tahap ini bertujuan untuk menyebarluaskan produk hasil pengembangan. Mengingat kondisi pandemi saat ini sehingga dilakukan penyebarluasan hasil penelitian melalui artikel ilmiah.

\section{SIMPULAN DAN SARAN}

Berdasarkan hasil analisis data dan pembahasan yang telah dilakukan dapat disimpulkan bahwa modul fisika berbasis guided inquiry yang dikembangkan dikatakan sangat layak digunakan dalam pembelajaran untuk meningkatkan kemampuan berpikir kritis karena hasil validasi tergolong kriteria sangat baik, efektif untuk menunjang kegiatan pembelajaran, karena hasil uji $n$-gain menunjukkan bahwa kemampuan berpikir kritis peserta didik mengalami peningkatan sebesar 
0,44 yang tergolong sedang, dan modul praktis untuk digunakan karena dilihat dari hasil analisis angket respon peserta didik yang tergolong positif.

Peneliti mengemukakan beberapa saran yaitu sebaiknya sebelum melaksanakan pembelajaran guru telah memahami karakteristik peserta didik dan mampu menguasai kelas. Begitupun untuk penelitian yang serupa dapat dilakukan dengan melibatkan lebih banya subjek dan kelas sebagai pembanding.

\section{UCAPAN TERIMAKASIH}

Ucapan terima kasih disampaikan kepada para validator ahli yang telah memberikan penilaian, saran, dan masukan terhadap modul fisika berbasis guided inquiry, sehingga modul ini dapat disusun dengan lebih baik. Terima kasih juga disampaikan kepada bapak ibu guru dan kepala SMAN 7 Mataram yang telah memfasilitasi pelaksanaan penelitian serta kepada semua pihak yang telah membantu sehingga hasil penelitian ini dapat dituangkan dan disebarluaskan dalam bentuk tulisan. Penulis berharap tulisan ini dapat bermanfaat dan menambah wawasan bagi para pembaca.

\section{DAFTAR RUJUKAN}

Al-Tabany, T. I. B. (2014). Mendesain model pembelajaran inovatif, progresif, dan kontekstual. In Prenadamedia Group.

Ariani, N. D., Masykuri, M., \& Suparmi, S. (2018). Pengembangan Modul Fisika Sma/Ma Kelas $X$ Berbasis Inkuiri Terbimbing Pada Materi Listrik Dinamis Untuk Meningkatkan Kemampuan Berpikir Kritis Siswa. INKUIRI: Jurnal Pendidikan IPA, 7(1), 93. https://doi.org/10.20961/inkuiri.v7i1.1979 4

Auliya, M., \& Kosim, K. (2017). Pengembangan Modul Fisika Materi Optik Dengan Pendekatan Saintifik Berbasis Fenomena Alam Untuk Meningkatkan Efektivitas Belajar Siswa Sma. Jurnal Pijar Mipa, 12(2), $\quad$ 71-80. https://doi.org/10.29303/jpm.v12i2.344

Azwar, S. (2012). Reliabilitas dan validitas edisi 4. Yogyakarta: Pustaka Pelajar.

Cahyono, B. (2017). ANALISIS KETRAMPILAN BERFIKIR KRITIS DALAM MEMECAHKAN MASALAH DITINJAU PERBEDAAN GENDER. AKSIOMA. https://doi.org/10.26877/aks.v8i1.1510

Fatmawati, A. (2016). Pengembangan Perangkat Pembelajaran Konsep Pencemaran Lingkungan Menggunkan Model Pembelajaran Berdasarkan
Volume 7, Nomor 1, Mei 2021. p-ISSN : 2460-9587 e-ISSN : 2614-7017

Masalah Untuk SMA Kelas X. EduSains.

Hartawati, Y., Harjono, A., \& Verawati, N. N. S. P. (2020). KEMAMPUAN BERPIKIR KRITIS MOMENTUM DAN IMPULS DITINJAU DARI GAYA BELAJAR PESERTA DIDIK DENGAN MODEL LEARNING CYCLE 5E. ORBITA: Jurnal Kajian, Inovasi Dan Aplikasi Pendidikan Fisika.

https://doi.org/10.31764/orbita.v6i1.1515

Haspen, C. D. T., \& Festiyed. (2019). MetaAnalisis Pengembangan E-Modul Berbasis Inkuiri Terbimbing Pada Pembelajaran Fisika. Jurnal Penelitian Pembelajaran Fisika, 5(2), 180-187.

Hendryadi, H. (2017). Validitas Isi: Tahap Awal Pengembangan Kuesioner. Jurnal Riset Manajemen Dan Bisnis (JRMB) Fakultas Ekonomi UNIAT, 2(2), 169-178. https://doi.org/10.36226/jrmb.v2i2.47

Mariana, E., Sukarmin, \& Cari. (2017). Untuk Meningkatkan Kemampuan Berpikir Kritis Siswa Sma / Ma Kelas X Pada Materi Listrik Dinamis. Jurnal Inkuiri, 6(2), 137146.

Matsun, M., \& Saputri, D. F. (2020). PENGEMBANGAN E-MODUL FISIKA BERBANTUAN WHATSAPP SEBAGAI ALTERNATIF PEMEBALAJARAN DIMASA PEMDEMI COVID 19. ORBITA: Jurnal Kajian, Inovasi Dan Aplikasi Pendidikan Fisika. https://doi.org/10.31764/orbita.v6i2.3130

Muldiyana, M., Ibrahim, N., \& Muslim, S. (2018). Pengembangan Modul Cetak Pada Mata Pelajaran Produktif Teknik Komputer Dan Jaringan Di SMK Negeri 2 Watampone. JTP - Jurnal Teknologi Pendidikan. https://doi.org/10.21009/jtp.v20i1.7845

Permana, N. (2017). Pemakaian Modul Pembelajaran Sejarah di SMA N 6 Padang. Jurnal Pendidikan Sejarah. https://doi.org/10.21009/jps.052.04

Purwanto, P., Rahadi, A. \& Lasmono, S. (2007). Pengembangan Modul. Jakarta: Pusat Teknologi Informasi dan Komunikasi Pendidikan Depdiknas.

Ristanti, V. N. D., Nurmilawati, M., \& Sulistyowati, T. I. (2019). Respon Siswa Terhadap Modul Pembelajaran Berbasis SAVI (Somatic, Auditory, Visualitation, Intellegency) pada Materi Ekosistem di SMAN 1 Papar. Jurnal Biologi dan Pembelajarannya, 6(1), 36-38

Sabaryati, J., \& Darmayanti, N. W. S. (2018). PENGEMBANGAN MODUL PRAKTIKUM FISIKA MODEL GUIDE INQUIRY BERBASIS COMPUTERIZED EXPERIMENT TOOL (CET) UNTUK PEMBENTUKAN KARAKTER ILMIAH 
SISWA. ORBITA: Jurnal Kajian, Inovasi Dan Aplikasi Pendidikan Fisika. https://doi.org/10.31764/orbita.v4i1.497

Sahidu, C. (2018). Pengembangan Program Pembelajaran Fisika (P3F). Mataram: FKIP Universitas Mataram.

Sugiyanto, S., Sunarno, W., \& Prayitno, B. (2013). Pengembangan Modul Berbasis Inkuiri Terbimbing Disertai Multimedia Pada Materi Keanekaragaman Makhluk Hidup Di Smpn 1 Kendal Kabupaten Ngawi. Bioedukasi UNS, 6(1), 22-33.

Sundayana, R. (2014). Statistika Penelitian Pendidikan. Bandung: Alfabeta.

Tangkas, I. (2012). PENGARUH IMPLEMENTASI MODEL PEMBELAJARAN INKUIRI TERBIMBING TERHADAP KEMAMPUAN PEMAHAMAN KONSEP DAN KETERAMPILAN PROSES SAINS SISWA KELAS X SMAN 3 AMLAPURA. Jurnal Pendidikan Dan Pembelajaran IPA Indonesia.

Trisna, S., \& Rahmi, A. (2016). Validitas Modul Pembelajaran Berbasis Guided Inquiry pada Materi Fluida di STKIP PGRI Sumatera Barat. Jurnal Penelitian \& Pengembangan Pendidikan Fisika. https://doi.org/10.21009/1.02102

Wati, M., Misbah, M., Ramadhaniah, N. I., \& Mahtari, S. (2017). Pengembangan Modul Fisika pada Pokok Bahasan Fluida Statik dengan Model Pembelajaran Sains Teknologi Masyarakat (STM) di SMAN 4 Banjarmasin. Proceeding Seminar Nasional IPA VIII. 